medRxiv preprint doi: https://doi.org/10.1101/2021.04.12.21255310; this version posted April 15, 2021. The copyright holder for this preprint (which was not certified by peer review) is the author/funder, who has granted medRxiv a license to display the preprint in perpetuity.

All rights reserved. No reuse allowed without permission.

\title{
Effective connectivity during faces processing in major depression - distinguishing markers of pathology, risk, and resilience
}

Seda Sacu 1, a, Carolin Wackerhagen 2, a, Susanne Erk 2, Nina Romanczuk-Seiferth 2, Kristina Schwarz ${ }^{3}$, Janina I. Schweiger ${ }^{3}$, Heike Tost ${ }^{3}$, Andreas Meyer-Lindenberg ${ }^{3}$, Andreas Heinz ${ }^{2}$, Adeel Razi ${ }^{4,5, b}$, Henrik Walter 1,2, b

${ }^{1}$ Berlin School of Mind and Brain, Humboldt Universität zu Berlin, Germany.

${ }^{2}$ Division of Mind and Brain Research, Department of Psychiatry and Psychotherapy CCM, Charité - Universitätsmedizin Berlin, corporate member of Freie Universität Berlin, HumboldtUniversität zu Berlin, and Berlin Institute of Health, Berlin, Germany

${ }^{3}$ Department of Psychiatry and Psychotherapy, Central Institute of Mental Health, Mannheim, Germany

${ }^{4}$ Wellcome Centre for Human Neuroimaging, Institute of Neurology, University College London, United Kingdom

${ }^{5}$ Turner Institute for Brain and Mental Health \& Monash Biomedical Imaging, Monash University, Australia

${ }^{\mathrm{a}}$ joint first authors ${ }^{\mathrm{b}}$ joint senior authors

Short title: Neural markers of pathology, risk and resilience in MDD

Keywords: Major depressive disorder; familial risk; resilience; emotional face processing; effective connectivity; fMRI.

\section{Corresponding author}

Dr. Carolin Wackerhagen

Klinik für Psychiatrie und Psychotherapie, CCM

Charité-Universitätsmedizin Berlin

Charitéplatz 1, 10117 Berlin

Email: carolin.wackerhagen@charite.de

Phone: +49 30450517229

\section{Word count}

Abstract: 233

Main text: 3998

\section{Other material}

3 Tables, 4 Figures

SWoppleminental. Information prearch that has not been certified by peer review and should not be used to guide clinical practice. 
medRxiv preprint doi: https://doi.org/10.1101/2021.04.12.21255310; this version posted April 15, 2021. The copyright holder for this preprint (which was not certified by peer review) is the author/funder, who has granted medRxiv a license to display the preprint in perpetuity.

All rights reserved. No reuse allowed without permission.

\begin{abstract}
Background: Aberrant brain connectivity during emotional processing, especially within the fronto-limbic pathway, is one of the hallmarks of major depressive disorder (MDD). However, a lack of systematic approaches in previous studies made it difficult to determine whether a specific alteration in brain connectivity reflects a cause, correlate, or effect of the disorder. The current study aimed to investigate neural mechanisms that correspond to disease, risk and resilience in major depression during implicit processing of emotion cues.
\end{abstract}

Methods: Forty-eight patients with MDD, 49 first-degree relatives of patients with MDD and 103 healthy controls performed a face-matching task during functional magnetic resonance imaging. We used dynamic causal modelling to estimate task-dependent effective connectivity at the subject level. Parametric empirical Bayes was then performed to quantify group differences in effective connectivity.

Results: Depressive pathology was associated with decreased effective connectivity from the left amygdala and left dorsolateral prefrontal cortex to the right fusiform gyrus, whereas familial risk for depression corresponded to decreased connectivity from the right orbitofrontal cortex to the left insula and from the left orbitofrontal cortex to the right fusiform gyrus. Resilience for depression was related to increased connectivity from the anterior cingulate cortex to the left dorsolateral prefrontal cortex.

Conclusions: Our results suggest that the depressive state alters top-down control of higher visual regions during the processing of emotional faces, whereas increased connectivity within the cognitive control network promotes resilience to depression. 
medRxiv preprint doi: https://doi.org/10.1101/2021.04.12.21255310; this version posted April 15, 2021. The copyright holder for this preprint (which was not certified by peer review) is the author/funder, who has granted medRxiv a license to display the preprint in perpetuity.

\section{Introduction}

Major depressive disorder (MDD) is a common and debilitating mental health problem with a well-known familial association (1). Due to the contribution of both genetic and environmental factors, individuals with a family history of MDD are at a greater risk for developing depression compared to those without a family history of MDD (2-5). However, the pathway from familial risk to clinical symptoms has not been fully understood in MDD.

Through the elevated risk of developing depression, unaffected first-degree relatives are assumed to share some biological and psychological features with MDD patients (6-7). Altered fronto-limbic connectivity is one of these putative risk markers which is associated with MDD and present independently from clinical status (8). Several studies showed that both depressed patients (9-16) and individuals with a family history of depression (17-19) exhibited decreased connectivity in the frontolimbic pathway during the processing of facial emotion. Although these results support that abnormal fronto-limbic connectivity can be a risk marker for MDD, previous studies compared either MDD patients or individuals at familial risk for MDD with healthy controls. Therefore, it is not clear to what extent alterations in the fronto-limbic pathways are shared by patients and individuals at familial risk for MDD. A systematic approach is, thus, necessary to dissociate disease-specific and risk-related alterations in this circuitry.

On the other hand, despite the familial risk for psychiatric disorders, which is comprised of both genetic and environmental factors, many first-degree relatives do not develop depression and stay psychologically healthy. This phenomenon can be described as resilience, i.e. the maintenance of mental health despite adversity (2021). It is possible that neural or neurodevelopmental mechanisms in healthy relatives 
medRxiv preprint doi: https://doi.org/10.1101/2021.04.12.21255310; this version posted April 15, 2021. The copyright holder for this preprint (which was not certified by peer review) is the author/funder, who has granted medRxiv a license to display the preprint in perpetuity.

All rights reserved. No reuse allowed without permission.

enable this resilience capacity, and that these are unique to the relatives group compared to both patients and controls. Given the high prevalence rate and poor treatment outcomes for MDD (22-23), identifying biopsychosocial factors promoting resilience, as well as the neural mechanism underlying it, becomes important to develop novel approaches to the prevention and treatment of depression (24).

Although research into the neuroscience of resilience is relatively new, previous studies have suggested that brain regions involved in cognitive control of emotions are associated with resilience to depression $(21,25)$. One of these brain regions associated with resilience capacity is the anterior cingulate cortex (24). Previous neuroimaging studies showed that resilience to depression is linked to greater anterior cingulate cortex volume (25-26), greater anterior cingulate cortex activation during a cognitive task (27) and enhanced connectivity between anterior cingulate cortex and the prefrontal cortex during the processing of emotional faces $(19,28)$. Taken together, these findings suggest that the connectivity of the anterior cingulate cortex may be a promising target to test resilience mechanism for MDD.

Here, we re-assessed data reported by Wackerhagen et al. (28) and adopted the same group-comparative approach (Supplementary Material S1) to disentangle disease, risk and resilience in neuro-functional markers for MDD during an implicit emotion processing task. However, instead of using generalized psychophysiological interactions (29) to assess task-dependent functional connectivity, we utilized Dynamic Causal Modelling (DCM) to measure effective connectivity in the target neural pathways. This brings two main methodological advantages to the present study. First, unlike functional connectivity, effective connectivity allows us to determine the direction of influences (i.e., causal relationships in the context of the model) as well as the valence of the influence (i.e., inhibitory or excitatory signaling) among coupled brain 
medRxiv preprint doi: https://doi.org/10.1101/2021.04.12.21255310; this version posted April 15, 2021. The copyright holder for this preprint (which was not certified by peer review) is the author/funder, who has granted medRxiv a license to display the preprint in perpetuity.

All rights reserved. No reuse allowed without permission.

regions (30-31). Second, the majority of task-dependent functional connectivity studies used amygdala as a seed region and investigated the amygdala connectivity with the rest of the brain in MDD patients and individuals at high risk for MDD. Although the amygdala plays a crucial role in depression, we wanted to allow for new insights into the neural model of MDD by utilizing a model-based approach that takes into account the connectivity patterns of other important brain regions, such as the prefrontal cortex (32-33) and high-level visual regions like the fusiform gyrus (34-36).

Based on our previous study (28), we hypothesized that decreased effective connectivity within the fronto-limbic pathway will be identified as disease and/or risk factor for MDD, whereas connectivity between anterior cingulate cortex and prefrontal cortex will be related to resilience to MDD. Additionally, there is a growing literature showing that MDD patients have functional abnormalities in visual cortex regions during emotional face processing (34-40). Therefore, we wanted to explore whether altered effective connectivity of fusiform gyrus will be associated with disease state and/or risk for MDD. Finally, we explored the relationship between negative affect and task-related connectivity to evaluate the functional relevance of potential alterations. 
medRxiv preprint doi: https://doi.org/10.1101/2021.04.12.21255310; this version posted April 15, 2021. The copyright holder for this preprint (which was not certified by peer review) is the author/funder, who has granted medRxiv a license to display the preprint in perpetuity.

All rights reserved. No reuse allowed without permission.

\section{Methods and Materials}

\section{Participants}

Forty-eight patients with MDD (34 females, mean age=31.25), 49 first-degree relatives of patients with MDD (33 females, mean age $=28.49)$ and 103 healthy controls (61 females, mean age=31.88) were selected from two multicenter studies on the neuro-genetic causes of major depression, schizophrenia, and bipolar disorder $(28,41)$. First-degree relatives were included in this study if they had at least one firstdegree relative diagnosed with MDD. Except for family history of MDD in first-degree relatives, neither first-degree relatives nor healthy controls had a personal or familial history of lifetime axis I disorders. Inclusion criteria for patients were a current diagnosis of a recurrent depressive disorder or a depressive episode that was either severe or had lasted for at least two years. Psychiatric history was confirmed using the German version of the Structured Clinical Interview for DSM-IV-TR Axis I Disorders (42). Thirtythree of the patients were receiving psychotropic medication at the time of the fMRI investigation (Supplementary Material Table S1). For further details of the study cohorts please see Wackerhagen et al. (28).

The study was approved by local ethics committees of the study sites. All participants provided written informed consent.

\section{Psychological Measurements}

The current level of negative affectivity was assessed using the Beck Depression Inventory (43), the depression scale of the Symptom Checklist-90 (SCL90-R;44), State-Trait Anxiety Inventory- State (STAI-S;45), State-Trait Anxiety Inventory- Trait (STAI-T;45), and the neuroticism scale of the NEO-Five Factor Inventory (NEO-FFl;46). A composite score of negative affect was computed for each participant based on BDI, SCL-90 Depression, STAI-T and NEO-FFI Neuroticism 
medRxiv preprint doi: https://doi.org/10.1101/2021.04.12.21255310; this version posted April 15, 2021. The copyright holder for this preprint (which was not certified by peer review) is the author/funder, who has granted medRxiv a license to display the preprint in perpetuity.

scales using principal component analysis (see Supplementary Material S3 for details of principal component analysis).

\section{Experimental Paradigm}

We used a block-designed fMRI task adapted from Hariri et al. (47) to investigate the neural correlates of implicit emotion processing. The task had two conditions: face-matching and shape-matching (Supplementary Material Figure S2). During the face-matching condition, participants were asked to match one of two simultaneously presented faces (angry or fearful faces) with the identical target face. During the sensorimotor control condition, participants matched geometric shapes similarly. Eight blocks (4 blocks for each condition) were presented in alternating order. Each block consisted of 6 trials of 5 seconds and started with a brief instruction. Total task duration was 256 seconds.

\section{Image Acquisition and Preprocessing}

The images were acquired on a Siemens Magnetom Trio (Siemens, Erlangen, Germany) 3T MRI scanner using identical scanning protocols. During the task, 135 functional images were obtained using an asymmetric gradient echo-planar sequence sensitive to blood oxygen level-dependent (BOLD) contrast (28 slices, TE= $30 \mathrm{~ms}$, TR $=2000 \mathrm{~ms}$, flip angle $=80^{\circ}, \mathrm{FoV}=192 \mathrm{~mm}$, voxel size $=3 \times 3 \times 4 \mathrm{~mm}$ ) .

$\begin{array}{lllll}\text { Image preprocessing was performed using } & \text { SPM }\end{array}$ (http://www.fil.ion.ucl.ac.uk/spm/) and included slice timing correction, motion correction, structural and functional image co-registration, segmentation, normalization to the Montreal Neurological Institute (MNI) 152 template, and smoothing using a kernel with a full-width half-maximum of $8 \mathrm{~mm}$. Furthermore, to quantify mean head motion for each participant, we computed frame-wise displacement based on rigid body transformation parameters $(48,49)$. For a detailed description of image acquisition and preprocessing, see Supplementary Material S5. 
medRxiv preprint doi: https://doi.org/10.1101/2021.04.12.21255310; this version posted April 15, 2021. The copyright holder for this preprint (which was not certified by peer review) is the author/funder, who has granted medRxiv a license to display the preprint in perpetuity.

\section{Generalized Linear Modeling}

Generalized Linear Modeling (GLM) implemented in SPM12 was performed to estimate brain responses. Each experimental condition (face-matching and shapematching) and instructions were convolved with a canonical hemodynamic response function. Six motion parameters and time series from WM and CSF were entered into the subject-level analysis as nuisance covariates to correct for motion and physiological noise.

At the group level, a one-sample t-test was performed to find brain regions showing the main effect of task (faces > shapes). Additionally, we conducted one-way ANOVA to examine group differences in the main effect of task. Age, sex, education, study site, and mean head motion were included in all analyses as covariates.

\section{Regions of Interest Selection}

Based on our GLM results, we selected the following regions of interests (ROIs) to use in subsequent DCM analysis: fusiform gyrus, amygdala, anterior cingulate cortex, dorsolateral prefrontal cortex, orbitofrontal cortex, and insula. All ROls were chosen bilaterally, except the anterior cingulate cortex. The model included 11 ROls in total. The MNI coordinates of the ROls can be seen in Table 1.

To account for individual differences in the peak locations of brain activation, we searched for the local maxima nearest to the group-level coordinates within anatomical boundaries of given ROls (thresholded at $p<0.05$, uncorrected). Regional responses were then summarized with the first-eigenvariate of all activated voxels within a $6 \mathrm{~mm}$ sphere of the subject-specific local maxima. For participants showing no experimental effect within a given $\mathrm{ROI}$, the first eigenvariate of time series was extracted from a $6 \mathrm{~mm}$ sphere of the group-level maximum (50). Participants who did not show consistent experimental effect for more than two ROls within a hemisphere were 
medRxiv preprint doi: https://doi.org/10.1101/2021.04.12.21255310; this version posted April 15, 2021. The copyright holder for this preprint (which was not certified by peer review) is the author/funder, who has granted medRxiv a license to display the preprint in perpetuity.

excluded from further analysis $(n=13)$. For a detailed description, see Supplementary Material S6.

\section{Dynamic Causal Modelling}

Effective connectivity was investigated using DCM for fMRI. DCM is a Bayesian framework which combines a biologically realistic neuronal model with a biophysically validated hemodynamic model to estimate neural responses from the observed fMRI signal. It models intrinsic connections within and between brain regions and modulation of these intrinsic connections by context-dependent inputs (For a detailed description, see Supplementary Material S7).

In this study, we wanted to investigate the effect of viewing emotional faces on intrinsic connections. For this purpose, we specified a fully connected model with 121 neural coupling parameters (see Supplementary Material Figure S5), which allowed us to compare all possible nested models within the network. The driving input (i.e., emotional faces) entered the model through bilateral fusiform gyri and propagated through the network via intrinsic connections. After the model estimation, we performed diagnostics to check the quality of the DCM model fitting to ensure that model inversion was successful (51). Participants whose explained variance by the model was less than $10 \%(n=8)$ were excluded from further analyses. The final sample for group-level DCM analyses included 179 participants (see Supplementary Material Figure S6 for the flow diagram of study participants).

\section{Empirical Bayes for Group DCM}

We quantified commonalities and group differences in effective connectivity using Parametric Empirical Bayes (PEB). The PEB is a hierarchical Bayesian framework to estimate effective connectivity parameters at the group level. Here, we set three PEB analyses to compare three groups (e.g., controls versus patients, 
medRxiv preprint doi: https://doi.org/10.1101/2021.04.12.21255310; this version posted April 15, 2021. The copyright holder for this preprint (which was not certified by peer review) is the author/funder, who has granted medRxiv a license to display the preprint in perpetuity.

All rights reserved. No reuse allowed without permission.

controls versus relatives and relatives versus patients). Age, sex, education, study site and mean head motion were included in all analyses as covariates (For a detailed description see Supplementary Material S9). Since PEB is a multivariate Bayesian GLM, in which all the connectivity parameters are fitted at once to optimize the model evidence, no correction for multiple comparisons is required in contrast to a frequentist approach.

After group differences in effective connectivity were determined, we used a similar framework as in Wackerhagen et al. (28) to associate these group differences with disease pathology, risk and resilience. For disease-related changes in effective connectivity, we looked at both 'controls versus patients' and 'relatives versus patients' contrasts and determined the connections which are altered in patients compared to both controls and relatives. In the same way, we looked at both 'controls versus patients' and 'controls versus relatives' contrasts to determine shared features by patients and relatives (i.e., risk-related changes). Finally, we looked at 'controls versus relatives' and 'relatives versus patients' contrasts and determined the connections which are altered in relatives compared to both patients and controls to identify resilience-related changes in effective connectivity.

In addition, we explored the associations between effective connectivity strengths and negative affect scores for each group separately using the PEB framework. 
medRxiv preprint doi: https://doi.org/10.1101/2021.04.12.21255310; this version posted April 15, 2021. The copyright holder for this preprint (which was not certified by peer review) is the author/funder, who has granted medRxiv a license to display the preprint in perpetuity.

\section{Results}

\section{Behavioral Results}

As shown in Table 2, groups did not differ in terms of age, sex, years of education and task performance. However, there were significant group differences in study site and head motion. Patients had significantly higher head motion (Mdn $=0.12$ ) than controls $(\mathrm{Mdn}=0.09, \mathrm{p}=0.04)$ and relatives $(\mathrm{Mdn}=0.08, \mathrm{p}<0.001)$. Moreover, as expected, the one-way ANOVA test revealed a significant main effect of group in all psychological measurements (For test statistics of post-hoc comparisons, see Supplementary Material Table S4).

\section{Task-Related Brain Activity}

Across participants, the face-matching task elicited more activation than the shape-matching task in the visual cortex, fusiform gyrus, dorsal prefrontal cortex, subcortical areas (thalamus, amygdala, hippocampus, putamen) and cerebellum ( $p<$ 0.05, whole-brain FWE corrected; Figure 1 and Supplementary Material Table S5). The shape-matching task elicited more activation than the face-matching task in bilateral parietal lobes, middle and anterior cingulate cortex, middle occipital cortex, and middle frontal gyrus ( $p<0.05$, whole-brain FWE corrected).

The one-way ANOVA test showed a significant effect of group on brain responses (faces $>$ shapes). Post-hoc group comparisons revealed that patients exhibited significantly decreased activation in visual cortex (bilateral lingual gyrus, superior occipital gyrus and calcarine sulcus) compared to controls and relatives ( $p<$ 0.05, whole-brain FWE corrected; Figure 1 and Supplementary Material Table S6. We did not observe any significant group difference between controls and relatives in taskrelated brain activation ( $p<0.05$, whole-brain FWE corrected). 
medRxiv preprint doi: https://doi.org/10.1101/2021.04.12.21255310; this version posted April 15, 2021. The copyright holder for this preprint (which was not certified by peer review) is the author/funder, who has granted medRxiv a license to display the preprint in perpetuity.

\section{Effective Connectivity}

Between-group differences in effective connectivity during faces-matching condition are listed in Table 3. We here report only the connection parameters with a probability greater than $95 \%$ (posterior probability $>0.95$ ), which corresponds to strong evidence. Having determined between-group differences, we identified connection parameters which were associated with depressive state, risk and resilience for MDD.

Disease state was associated with lower effective connectivity from left amygdala and left dorsolateral prefrontal cortex to right fusiform gyrus and from left orbitofrontal cortex to left fusiform gyrus (Figure 2). As seen in Figure 2, the estimated group means for these intrinsic connection parameters had negative values. That is, high activity in the source region leads to a decrease in activity in the target region (i.e., inhibitory influence). Thus, lower effective connectivity observed in MDD patients corresponds to more inhibitory influence from amygdala and frontal regions to fusiform gyrus. Furthermore, analysis of brain-behavior relationships revealed that effective connectivity from left amygdala to right fusiform gyrus was negatively associated with negative affect scores in MDD patients (standardized $\beta$ coefficient $=-0.08$, posterior probability $>0.95)$, whereas effective connectivity from left dorsolateral prefrontal cortex to right fusiform gyrus was positively associated with negative affect scores in MDD patients (standardized $\beta$ coefficient $=0.08$, posterior probability $>0.95$ ).

Risk for MDD was associated with decreased effective connectivity from right orbitofrontal cortex to left insula and from the left orbitofrontal cortex to right fusiform gyrus (Figure 3). Controls exhibited higher effective connectivity in these connection parameters compared to relatives and patients. In addition, the alteration in effective connectivity from left orbitofrontal cortex to right fusiform gyrus was gradual (patients 
medRxiv preprint doi: https://doi.org/10.1101/2021.04.12.21255310; this version posted April 15, 2021. The copyright holder for this preprint (which was not certified by peer review) is the author/funder, who has granted medRxiv a license to display the preprint in perpetuity.

All rights reserved. No reuse allowed without permission.

$<$ relatives < controls) and negatively associated with negative affect scores in MDD patients (standardized $\beta$ coefficient $=-0.11$, posterior probability $>0.95$ ).

Effective connectivity from anterior cingulate cortex to left dorsolateral prefrontal cortex was elevated in relatives compared to controls and patients in the resilience contrast (Figure 4). A positive association between negative affect scores and connectivity strength was detected in MDD patients (standardized $\beta$ coefficient $=0.13$, posterior probability $>0.95)$. 
medRxiv preprint doi: https://doi.org/10.1101/2021.04.12.21255310; this version posted April 15, 2021. The copyright holder for this preprint (which was not certified by peer review) is the author/funder, who has granted medRxiv a license to display the preprint in perpetuity.

All rights reserved. No reuse allowed without permission.

\section{Discussion}

The present study investigated brain responses and effective connectivity during the face-matching task in patients with MDD, unaffected first-degree relatives and healthy participants. Our results revealed that the groups differed in task-related activity and effective connectivity in the absence of group differences in task performance.

\section{Disease State}

Compared to relatives and controls, MDD patients exhibited lower activity in several visual areas and lower effective connectivity (i.e., more inhibitory influence) from higher order areas to fusiform gyrus during the face-matching task. Specifically, MDD patients showed more inhibitory influence from the left amygdala to right fusiform gyrus than controls and relatives. This increased inhibitory influence was also associated with higher negative affect in MDD patients. Several studies showed that the amygdala has a modulatory role over the visual cortex during emotional face processing (52-57). It can enhance or diminish sensory representation of a stimulus in visual regions based on its motivational significance (58). More inhibitory influence in patients with higher negative affect indicates that this alteration could arise due to an increased perception of negative emotion (59). The fusiform gyrus has a crucial role in face processing and social perception (60-64), therefore, excessive inhibition of fusiform gyrus activity by amygdala can cause diminished visual attention to motivationally important stimuli in MDD patients.

Additionally, disease pathology was associated with increased inhibitory influence from the lateral prefrontal regions to fusiform gyrus. MDD patients with higher negative affect also exerted less inhibitory influence from left dorsolateral prefrontal cortex to right fusiform gyrus. These results are compatible with previous studies 
medRxiv preprint doi: https://doi.org/10.1101/2021.04.12.21255310; this version posted April 15, 2021. The copyright holder for this preprint (which was not certified by peer review) is the author/funder, who has granted medRxiv a license to display the preprint in perpetuity.

All rights reserved. No reuse allowed without permission.

reporting decreased functional connectivity between frontal and visual regions in MDD patients during an emotional task (65-66) and at resting-state (67-69). The lateral prefrontal cortex plays an important role in the integration of cognitive and emotional information (70-71) and inhibition of task-irrelevant stimuli (72-74). Moreover, similar to the amygdala, it can modulate the activation of sensory and association cortices (7576). Previous studies showed that emotional stimulus can interfere goal-directed behavior (72), and top-down control of emotional distractors can result in better task performance (77-78). Therefore, more inhibitory influence detected in patients could be related to inhibition of emotional distractors (e.g., facial expression) during the identity matching and contribute to maintaining the same level of task performance with controls and relatives by preventing the disruptive effect of emotional distractors on working memory (77). However, due to the lack of variability in task performance, we could not test this hypothesis. Moreover, the utilized task is not cognitively challenging. Therefore, the alleged compensatory mechanism cannot be generalized to cognitively demanding tasks since MDD patients may fail to inhibit emotional distractors when task difficulty increases.

\section{Risk}

Decreased effective connectivity from right orbitofrontal cortex to the left insula was associated with risk for MDD. The insula has been related to affective processing and has bidirectional connections with orbitofrontal cortex (79). The increased coupling between the insula and prefrontal cortex in healthy controls was linked to attenuated distraction (80) and decreased negative emotion during suppression (81). Thus, the increased fronto-insular effective connectivity in controls may reflect a functional mechanism, possibly suppression of irrelevant information, which helps participants to deal with emotional distractors, whereas decreased effective connectivity in patients 
medRxiv preprint doi: https://doi.org/10.1101/2021.04.12.21255310; this version posted April 15, 2021. The copyright holder for this preprint (which was not certified by peer review) is the author/funder, who has granted medRxiv a license to display the preprint in perpetuity.

All rights reserved. No reuse allowed without permission.

and relatives might reflect increased attention to negative facial expressions and lower suppression success.

Furthermore, similar to MDD patients, relatives exhibited decreased connectivity from left orbitofrontal cortex to right fusiform gyrus compared to controls. A recent study reported that the main effect of familial risk for depression (i.e., patients and healthy controls with versus without family history of MDD) was associated with altered functional connectivity between the orbitofrontal cortex and visual regions (82). Although we did not directly investigate the main effect of familial risk in this study in the same way, our results indicate that orbitofrontal cortex might be an important brain region to investigate risk-related changes in depression.

Contrary to our hypothesis, we did not identify decreased effective connectivity between the amygdala and frontal regions as a putative risk marker for depression. In line with previous studies (11-12,14,83-84), MDD patients showed decreased effective connectivity from left dorsolateral prefrontal cortex to left amygdala compared to controls. However, relatives did not differ from either controls or patients given the strong evidence (posterior probability $>0.95$ ). Although evidence from separate studies support that both MDD patients and individuals at familial risk for MDD exhibit altered amygdala connectivity with the prefrontal cortex, the precise location of the coupling region within the prefrontal cortex may differ according to the groups. Since our DCM included only lateral prefrontal regions (BA 46 and 47) due to their prominent activation during the face-matching task, other prefrontal regions which are not included in the model, such as medial prefrontal regions $(18,28)$, may play a more important role in risk for MDD.

\section{Resilience}


medRxiv preprint doi: https://doi.org/10.1101/2021.04.12.21255310; this version posted April 15, 2021. The copyright holder for this preprint (which was not certified by peer review) is the author/funder, who has granted medRxiv a license to display the preprint in perpetuity.

All rights reserved. No reuse allowed without permission.

During the face-matching task, relatives had higher effective connectivity from anterior cingulate cortex to left dorsolateral prefrontal cortex than controls and patients. Similar to the present findings, increased functional connectivity between the anterior cingulate cortex and left superior frontal gyrus in first-degree relatives was reported in our previous study as a marker of resilience (28). The anterior cingulate cortex is responsible for various aspects of emotional processing (85-86) and constitutes the cognitive-control network together with the dorsolateral prefrontal cortex (39). Previous studies have linked the neural coupling between the anterior cingulate cortex and the dorsolateral prefrontal cortex to a better performance in attention shifting (87) and increased top-down attentional control (88) in healthy participants. Thus, enhanced fronto-cingulate connectivity in relatives can serve as a resilience capacity mechanism by providing more cognitive control during affective face processing.

Interestingly, enhanced connectivity from the anterior cingulate cortex to dorsolateral prefrontal cortex was related to increased negative affect in MDD patients. Although previous studies associated enhanced fronto-cingulate connectivity with positive outcomes in healthy participants, this connection may have an altered association in MDD. Indeed, a recent study showed that weaker connectivity between anterior cingulate cortex and dorsolateral prefrontal cortex was beneficial for depression recovery in MDD patients before and after eight weeks of antidepressant treatment (89).

Furthermore, it is important to note that we here attempted to identify resiliencerelated changes in effective connectivity using a cross-sectional design. Although it brings some practical advantages, it is challenging to deem a unique feature as a resilience marker, first-degree relatives still have a chance of developing depression in future given the relatively wide range of age of onset of this disorder (90). Therefore, 
medRxiv preprint doi: https://doi.org/10.1101/2021.04.12.21255310; this version posted April 15, 2021. The copyright holder for this preprint (which was not certified by peer review) is the author/funder, who has granted medRxiv a license to display the preprint in perpetuity.

All rights reserved. No reuse allowed without permission.

a unique alteration found in first-degree relatives can also reflect a risk marker that occurs before the onset of disease (28).

\section{Limitations}

Our findings need to be interpreted in the light of some limitations. First, we assume that our experimental design measure neural responses to implicit emotional processing since all faces embodied expressions of emotion. However, the utilization of geometrical shapes in the control condition instead of neutral faces made it impossible to dissociate the effect of emotional valance from basic face processing. Thus, we could not investigate the direct effect of the emotional valance on brain activity and connectivity in this study.

Second, the current concept of resilience (20) requires that measures of stressor-load should be put into relation with symptomatology across time to assess resilience as an outcome. Therefore, the potential protective mechanisms found in our group comparisons might be of compensatory nature and their relevance for resilient stress-coping needs to be further evaluated.

Lastly, we here used DCM as a causal search paradigm by specifying a fullyconnected model. Connection parameters which did not contribute to model evidence were then pruned away from the model. This procedure uses a greedy search algorithm which finds the best solution at each step rather than comparing all possible nested models. When the number of ROls in the model increased, model space grows exponentially, and using a greedy search algorithm with large model space can introduce bias to construct post-hoc explanations for the surviving parameters (91).

\section{Conclusion}


medRxiv preprint doi: https://doi.org/10.1101/2021.04.12.21255310; this version posted April 15, 2021. The copyright holder for this preprint (which was not certified by peer review) is the author/funder, who has granted medRxiv a license to display the preprint in perpetuity.

All rights reserved. No reuse allowed without permission.

Our results suggest that the depressive state alters top-down control of higher visual regions, which are important for emotional face processing, whereas enhanced connectivity within the cognitive control network facilitates the capacity for resilience or compensation for familial risk factors. If further research, particularly longitudinal studies, supports these hypotheses, brain regions whose activity and connectivity pattern are related to the depressive state, risk and resilience can be used as targets in novel treatments of depression, such as neurofeedback (92-95). 
medRxiv preprint doi: https://doi.org/10.1101/2021.04.12.21255310; this version posted April 15, 2021. The copyright holder for this preprint (which was not certified by peer review) is the author/funder, who has granted medRxiv a license to display the preprint in perpetuity.

\section{Acknowledgements}

The authors would like to thank Prof. Karl Friston for his valuable suggestions on the application of DCM and Dr. Peter Zeidman for his assistance with DCM analysis.

\section{Funding}

This work was funded by the German Federal Ministry for Education and Research (BMBF) grants NGFNplus MooDS (Systematic Investigation of the Molecular Causes of Major Mood Disorders and Schizophrenia) and the Integrated Network IntegraMent (Integrated Understanding of Causes and Mechanisms in Mental Disorders) under the auspices of th e:Med program (grant numbers O1ZX1314B and O1ZX1314G).

A.R. is funded by the Australian Research Council (Refs: DE170100128 and DP200100757) and Australian National Health and Medical Research Council Investigator Grant (Ref: 1194910).

\section{Financial Disclosures}

A.M.-L. has received consultant fees from Boehringer Ingelheim, Elsevier, Walt Disney Pictures, Brainsway, Lundbeck Int. Neuroscience Foundation, Sumitomo Dainippon Pharma Co., Academic Medical Center of the University of Amsterdam, Synapsis Foundation-Alzheimer Research Switzerland, IBS Center for Synaptic Brain Dysfunction, Blueprint Partnership, University of Cambridge, Dt. Zentrum für Neurodegenerative Erkrankungen, Universität Zürich, L.E.K. Consulting, ICARE Schizophrenia, Science Advances, and has received fees for lectures, interviews and travels from Lundbeck International Foundation, Paul-Martini-Stiftung, Lilly Deutschland, Atheneum, Fama Public Relations, Institut d'investigacions Biomèdiques August Pi i Sunyer (IDIBAPS), Jansen-Cilag, Hertie Stiftung, Bodelschwingh-Klinik, Pfizer, Atheneum, Universität Freiburg, Schizophrenia Academy, Hong Kong Society 
medRxiv preprint doi: https://doi.org/10.1101/2021.04.12.21255310; this version posted April 15, 2021. The copyright holder for this preprint (which was not certified by peer review) is the author/funder, who has granted medRxiv a license to display the preprint in perpetuity. All rights reserved. No reuse allowed without permission.

of Biological Psychiatry, Fama Public Relations, Spanish Society of Psychiatry, Reunions I Ciencia S.L., Brain Center Rudolf Magnus UMC Utrecht.

All other authors report no biomedical financial interests or potential conflicts of interest. 
medRxiv preprint doi: https://doi.org/10.1101/2021.04.12.21255310; this version posted April 15, 2021. The copyright holder for this preprint (which was not certified by peer review) is the author/funder, who has granted medRxiv a license to display the preprint in perpetuity.

\section{References}

1. Sullivan PF, Neale MC, Kendler KS (2000): Genetic epidemiology of major depression: Review and meta-analysis. American Journal of Psychiatry. https://doi.org/10.1176/appi.ajp.157.10.1552

2. Klein DN, Glenn CR, Kosty DB, Seeley JR, Rohde P, Lewinsohn PM (2013):

Predictors of first lifetime onset of major depressive disorder in young adulthood. J Abnorm Psychol. https://doi.org/10.1037/a0029567

3. Li X, Sundquist K, Hemminki K, Sundquist J (2008): Familial risks for depression among siblings based on hospitalizations in Sweden. Psychiatr Genet. https://doi.org/10.1097/YPG.0b013e3282f08ac9

4. Weissman MM, Wickramaratne $P$, Nomura $Y$, Warner V, Pilowsky D, Verdeli $H$ (2006): Offspring of depressed parents: 20 Years later. Am J Psychiatry. https://doi.org/10.1176/ajp.2006.163.6.1001

5. Wilde A, Chan HN, Rahman B, Meiser B, Mitchell PB, Schofield PR, Green MJ (2014): A meta-analysis of the risk of major affective disorder in relatives of individuals affected by major depressive disorder or bipolar disorder. J Affect Disord. https://doi.org/10.1016/j.jad.2014.01.014

6. Hasler G, Drevets WC, Manji HK, Charney DS (2004): Discovering endophenotypes for major depression. Neuropsychopharmacol.

7. Meyer-Lindenberg A, Weinberger DR (2006): Intermediate phenotypes and genetic mechanisms of psychiatric disorders. Nature Reviews Neuroscience. https://doi.org/10.1038/nrn1993

8. Fornito A, Bullmore ET (2012): Connectomic intermediate phenotypes for psychiatric disorders. Frontiers in Psychiatry. 
medRxiv preprint doi: https://doi.org/10.1101/2021.04.12.21255310; this version posted April 15, 2021. The copyright holder for this preprint (which was not certified by peer review) is the author/funder, who has granted medRxiv a license to display the preprint in perpetuity.

https://doi.org/10.3389/fpsyt.2012.00032

9. De Almeida JRC, Kronhaus DM, Sibille EL, Langenecker SA, Versace A, LaBarbara EJ, Phillips ML (2011): Abnormal left-sided orbitomedial prefrontal cortical-amygdala connectivity during happy and fear face processing: A potential neural mechanism of female MDD. Front Psychiatry. https://doi.org/10.3389/fpsyt.2011.00069

10. Carballedo A, Scheuerecker J, Meisenzahl E, Schoepf V, Bokde A, Möller HJ, et al. (2011): Functional connectivity of emotional processing in depression. $J$ Affect Disord. https://doi.org/10.1016/j.jad.2011.06.021

11. Chen $\mathrm{CH}$, Suckling J, Ooi C, Fu CHY, Williams SCR, Walsh ND, et al. (2008): Functional coupling of the amygdala in depressed patients treated with antidepressant medication. Neuropsychopharmacology. https://doi.org/10.1038/sj.npp.1301593

12. Dannlowski U, Ohrmann P, Konrad C, Domschke K, Bauer J, Kugel H, et al. (2009): Reduced amygdalaprefrontal coupling in major depression: Association with MAOA genotype and illness severity. Int J Neuropsychopharmacol. https://doi.org/10.1017/S1461145708008973

13. Kong L, Chen K, Tang Y, Wu F, Driesen N, Womer F, et al. (2013): Functional connectivity between the amygdala and prefrontal cortex in medication-naive individuals with major depressive disorder. J Psychiatry Neurosci. https://doi.org/10.1503/jpn.120117

14. Lu Q, Li H, Luo G, Wang Y, Tang H, Han L, Yao Z (2012): Impaired prefrontalamygdala effective connectivity is responsible for the dysfunction of emotion process in major depressive disorder: A dynamic causal modeling study on 
medRxiv preprint doi: https://doi.org/10.1101/2021.04.12.21255310; this version posted April 15, 2021. The copyright holder for this preprint (which was not certified by peer review) is the author/funder, who has granted medRxiv a license to display the preprint in perpetuity. All rights reserved. No reuse allowed without permission.

MEG. Neurosci Lett. https://doi.org/10.1016/j.neulet.2012.06.058

15. Matthews SC, Strigo IA, Simmons AN, Yang TT, Paulus MP (2008): Decreased functional coupling of the amygdala and supragenual cingulate is related to increased depression in unmedicated individuals with current major depressive disorder. J Affect Disord. https://doi.org/10.1016/j.jad.2008.05.022

16. Moses-Kolko EL, Perlman SB, Wisner KL, James J, Saul AT, Phillips ML (2010): Abnormally reduced dorsomedial prefrontal cortical activity and effective connectivity with amygdala in response to negative emotional faces in postpartum depression. Am J Psychiatry. https://doi.org/10.1176/appi.ajp.2010.09081235

17. Miskowiak KW, Glerup L, Vestbo C, Harmer CJ, Reinecke A, Macoveanu J, et al. (2015): Different neural and cognitive response to emotional faces in healthy monozygotic twins at risk of depression. Psychol Med. https://doi.org/10.1017/S0033291714002542

18. Miskowiak KW, Svendsen AMB, Harmer CJ, Elliott R, Macoveanu J, Siebner HR, et al. (2017): Differences in neural and cognitive response to emotional faces in middle-aged dizygotic twins at familial risk of depression. Psychol Med. https://doi.org/10.1017/S0033291717000861

19. Wackerhagen C, Wüstenberg T, Mohnke S, Erk S, Veer IM, Kruschwitz JD, et al. (2017): Influence of Familial Risk for Depression on Cortico-Limbic Connectivity during Implicit Emotional Processing. Neuropsychopharmacology. https://doi.org/10.1038/npp.2017.59

20. Kalisch R, Baker DG, Basten U, Boks MP, Bonanno GA, Brummelman E, et al. (2017): The resilience framework as a strategy to combat stress-related 
medRxiv preprint doi: https://doi.org/10.1101/2021.04.12.21255310; this version posted April 15, 2021. The copyright holder for this preprint (which was not certified by peer review) is the author/funder, who has granted medRxiv a license to display the preprint in perpetuity. All rights reserved. No reuse allowed without permission.

disorders. Nature Human Behaviour. https://doi.org/10.1038/s41562-017-0200-8

21. Rodman AM, Jenness JL, Weissman DG, Pine DS, McLaughlin KA (2019):

Neurobiological Markers of Resilience to Depression Following Childhood

Maltreatment: The Role of Neural Circuits Supporting the Cognitive Control of Emotion. Biol Psychiatry. https://doi.org/10.1016/j.biopsych.2019.04.033

22. Eckshtain D, Kuppens S, Ugueto A, Ng MY, Vaughn-Coaxum R, Corteselli K, Weisz JR (2020): Meta-Analysis: 13-Year Follow-up of Psychotherapy Effects on Youth Depression. Journal of the American Academy of Child and Adolescent Psychiatry. https://doi.org/10.1016/j.jaac.2019.04.002

23. Kessler RC, Bromet EJ (2013): The epidemiology of depression across cultures. Annual Review of Public Health. https://doi.org/10.1146/annurev-publhealth031912-114409

24. Holz NE, Tost H, Meyer-Lindenberg A (2020): Resilience and the brain: a key role for regulatory circuits linked to social stress and support. Molecular Psychiatry. https://doi.org/10.1038/s41380-019-0551-9

25. Gupta A, Love A, Kilpatrick LA, Labus JS, Bhatt R, Chang L, et al. (2017): Morphological brain measures of cortico-limbic inhibition related to resilience. $J$ Neurosci Res. https://doi.org/10.1002/jnr.24007

26. Holz NE, Boecker R, Jennen-Steinmetz C, Buchmann AF, Blomeyer D, Baumeister S, et al. (2016): Positive coping styles and perigenual ACC volume: Two related mechanisms for conferring resilience? Soc Cogn Affect Neurosci. https://doi.org/10.1093/scan/nsw005

27. Peterson BS, Wang Z, Horga G, Warner V, Rutherford B, Klahr KW, et al. (2014): Discriminating risk and resilience endophenotypes from lifetime illness effects in 
medRxiv preprint doi: https://doi.org/10.1101/2021.04.12.21255310; this version posted April 15, 2021. The copyright holder for this preprint (which was not certified by peer review) is the author/funder, who has granted medRxiv a license to display the preprint in perpetuity. All rights reserved. No reuse allowed without permission.

familial major depressive disorder. JAMA Psychiatry.

https://doi.org/10.1001/jamapsychiatry.2013.4048

28. Wackerhagen C, Veer IM, Erk S, Mohnke S, Lett TA, Wüstenberg T, et al. (2019): Amygdala functional connectivity in major depression-disentangling markers of pathology, risk and resilience. Psychol Med.

https://doi.org/10.1017/S0033291719002885

29. McLaren DG, Ries ML, Xu G, Johnson SC (2012): A generalized form of contextdependent psychophysiological interactions (gPPI): A comparison to standard approaches. Neuroimage. https://doi.org/10.1016/j.neuroimage.2012.03.068

30. Friston KJ, Harrison L, Penny W (2003): Dynamic causal modelling. Neuroimage. https://doi.org/10.1016/S1053-8119(03)00202-7

31. Friston KJ (2011): Functional and Effective Connectivity: A Review. Brain Connect. https://doi.org/10.1089/brain.2011.0008

32. Koenigs M, Huey ED, Calamia M, Raymont V, Tranel D, Grafman J (2008): Distinct regions of prefrontal cortex mediate resistance and vulnerability to depression. J Neurosci. https://doi.org/10.1523/JNEUROSCI.2324-08.2008

33. Pizzagalli DA (2011): Frontocingulate dysfunction in depression: Toward biomarkers of treatment response. Neuropsychopharmacology. https://doi.org/10.1038/npp.2010.166

34. Townsend JD, Eberhart NK, Bookheimer SY, Eisenberger NI, Foland-Ross LC, Cook IA, et al. (2010): FMRI activation in the amygdala and the orbitofrontal cortex in unmedicated subjects with major depressive disorder. Psychiatry Res Neuroimaging. https://doi.org/10.1016/j.pscychresns.2010.06.001 
medRxiv preprint doi: https://doi.org/10.1101/2021.04.12.21255310; this version posted April 15, 2021. The copyright holder for this preprint (which was not certified by peer review) is the author/funder, who has granted medRxiv a license to display the preprint in perpetuity.

35. Li J, Xu C, Cao X, Gao Q, Wang Y, Wang Y, et al. (2013): Abnormal activation of the occipital lobes during emotion picture processing in major depressive disorder patients. Neural Regen Res.

36. Ho TC, Zhang S, Sacchet MD, Weng H, Connolly CG, Henje Blom E, et al. (2016): Fusiform Gyrus Dysfunction is Associated with Perceptual Processing Efficiency to Emotional Faces in Adolescent Depression: A Model-Based Approach. Front Psychol. https://doi.org/10.3389/fpsyg.2016.00040

37. Furey ML, Drevets WC, Hoffman EM, Frankel E, Speer AM, Zarate CA (2013): Potential of pretreatment neural activity in the visual cortex during emotional processing to predict treatment response to scopolamine in major depressive disorder. JAMA Psychiatry. https://doi.org/10.1001/2013.jamapsychiatry.60

38. Colich NL, Foland-Ross LC, Eggleston C, Singh MK, Gotlib IH (2016): Neural Aspects of Inhibition Following Emotional Primes in Depressed Adolescents. $J$ Clin Child Adolesc Psychol. https://doi.org/10.1080/15374416.2014.982281

39. Li BJ, Friston K, Mody M, Wang HN, Lu HB, Hu DW (2018): A brain network model for depression: From symptom understanding to disease intervention. CNS Neuroscience and Therapeutics. https://doi.org/10.1111/cns.12998

40. Alders GL, Davis AD, MacQueen G, Strother SC, Hassel S, Zamyadi M, et al. (2019): Reduced accuracy accompanied by reduced neural activity during the performance of an emotional conflict task by unmedicated patients with major depression: A CAN-BIND fMRI study. J Affect Disord. https://doi.org/10.1016/j.jad.2019.07.037

41. Erk S, Meyer-Lindenberg A, Schmierer P, Mohnke S, Grimm O, Garbusow M, et al. (2014): Hippocampal and frontolimbic function as intermediate phenotype for 
medRxiv preprint doi: https://doi.org/10.1101/2021.04.12.21255310; this version posted April 15, 2021. The copyright holder for this preprint (which was not certified by peer review) is the author/funder, who has granted medRxiv a license to display the preprint in perpetuity.

All rights reserved. No reuse allowed without permission.

psychosis: Evidence from healthy relatives and a common risk variant in cacna1c. Biol Psychiatry. https://doi.org/10.1016/j.biopsych.2013.11.025

42. Wittchen H-U, Zaudig M, Fydrich T (1997): SKID. Strukturiertes Klinisches Interview für DSM-IV. Achse I und II. Handanweisung. Hogrefe. https://doi.org/10.1026//0084-5345.28.1.68

43. Hautzinger M, Bailer M, Worall H, Keller F (1994): Beck-depressions-inventar (BDI). Bern: Huber. https://doi.org/10.1016/j.jcv.2008.06.013

44. Derogatis LR (1977): SCL-90-R. Administration, scoring, and procedures manual I for the revised version od the SCL-90. John Hopkins Univ Press. https://doi.org/10.1098/rspb.2018.1084

45. Spielberger CD, Gorsuch RL, Lushene RE (1970): The State-Trait Anxiety Inventory Manual. MANUAL. https://doi.org/10.1037/t06496-000

46. Costa PT, McCrae RR (1992): Normal Personality Assessment in Clinical Practice: The NEO Personality Inventory. Psychol Assess. https://doi.org/10.1037/1040-3590.4.1.5

47. Hariri AR, Mattay VS, Tessitore A, Kolachana B, Fera F, Goldman D, et al. (2002): Serotonin transporter genetic variation and the response of the human amygdala. Science (80- ). https://doi.org/10.1126/science.1071829

48. Power JD, Barnes KA, Snyder AZ, Schlaggar BL, Petersen SE (2012): Spurious but systematic correlations in functional connectivity MRI networks arise from subject motion. Neuroimage. https://doi.org/10.1016/j.neuroimage.2011.10.018

49. Power JD, Mitra A, Laumann TO, Snyder AZ, Schlaggar BL, Petersen SE (2014): Methods to detect, characterize, and remove motion artifact in resting state fMRI. 
medRxiv preprint doi: https://doi.org/10.1101/2021.04.12.21255310; this version posted April 15, 2021. The copyright holder for this preprint (which was not certified by peer review) is the author/funder, who has granted medRxiv a license to display the preprint in perpetuity.

Neuroimage. https://doi.org/10.1016/j.neuroimage.2013.08.048

50. Zhou Y, Zeidman P, Wu S, Razi A, Chen C, Yang L, et al. (2018): Altered intrinsic and extrinsic connectivity in schizophrenia. Neurolmage Clin.

https://doi.org/10.1016/j.nicl.2017.12.006

51. Zeidman P, Jafarian A, Seghier ML, Litvak V, Cagnan H, Cathy J, et al. (2019): A tutorial on group effective connectivity analysis, part 1: first level analysis with DCM for fMRI. Arxiv.

52. Morris JS, Friston KJ, Büchel C, Frith CD, Young AW, Calder AJ, Dolan RJ (1998): A neuromodulatory role for the human amygdala in processing emotional facial expressions. Brain. https://doi.org/10.1093/brain/121.1.47

53. Vuilleumier P, Armony JL, Driver J, Dolan RJ (2001): Effects of attention and emotion on face processing in the human brain: An event-related fMRI study. Neuron. https://doi.org/10.1016/S0896-6273(01)00328-2

54. Vuilleumier P, Richardson MP, Armony JL, Driver J, Dolan RJ (2004): Distant influences of amygdala lesion on visual cortical activation during emotional face processing. Nat Neurosci. https://doi.org/10.1038/nn1341

55. Das P, Kemp AH, Liddell BJ, Brown KJ, Olivieri G, Peduto A, et al. (2005): Pathways for fear perception: Modulation of amygdala activity by thalamocortical systems. Neuroimage. https://doi.org/10.1016/j.neuroimage.2005.01.049

56. Williams LM (2006): Mode of Functional Connectivity in Amygdala Pathways Dissociates Level of Awareness for Signals of Fear. J Neurosci. https://doi.org/10.1523/jneurosci.1016-06.2006

57. Furl N, Henson RN, Friston KJ, Calder AJ (2013): Top-down control of visual 
medRxiv preprint doi: https://doi.org/10.1101/2021.04.12.21255310; this version posted April 15, 2021. The copyright holder for this preprint (which was not certified by peer review) is the author/funder, who has granted medRxiv a license to display the preprint in perpetuity.

All rights reserved. No reuse allowed without permission.

responses to fear by the amygdala. $J$ Neurosci.

https://doi.org/10.1523/JNEUROSCI.2992-13.2013

58. Pessoa L, Adolphs R (2010): Emotion processing and the amygdala: From a "low road" to "many roads" of evaluating biological significance. Nature Reviews Neuroscience. https://doi.org/10.1038/nrn2920

59. Miyahara M, Harada T, Ruffman T, Sadato N, lidaka T (2013): Functional connectivity between amygdala and facial regions involved in recognition of facial threat. Soc Cogn Affect Neurosci. https://doi.org/10.1093/scan/nsr085

60. Haxby J V., Hoffman EA, Gobbini MI (2000): The distributed human neural system for face perception. Trends in Cognitive Sciences.

https://doi.org/10.1016/S1364-6613(00)01482-0

61. Haxby J V., Hoffman EA, Gobbini MI (2002): Human neural systems for face recognition and social communication. Biol Psychiatry. https://doi.org/10.1016/S0006-3223(01)01330-0

62. Fisher K, Towler J, Eimer M (2016): Facial identity and facial expression are initially integrated at visual perceptual stages of face processing. Neuropsychologia. https://doi.org/10.1016/j.neuropsychologia.2015.11.011

63. Fairhall SL, Ishai A (2007): Effective connectivity within the distributed cortical network for face perception. Cereb Cortex. https://doi.org/10.1093/cercor/bhl148

64. Bickart KC, Dickerson BC, Barrett LF (2014): The amygdala as a hub in brain networks that support social life. Neuropsychologia.

https://doi.org/10.1016/j.neuropsychologia.2014.08.013

65. Frodl T, Bokde ALW, Scheuerecker J, Lisiecka D, Schoepf V, Hampel H, et al. 
medRxiv preprint doi: https://doi.org/10.1101/2021.04.12.21255310; this version posted April 15, 2021. The copyright holder for this preprint (which was not certified by peer review) is the author/funder, who has granted medRxiv a license to display the preprint in perpetuity.

All rights reserved. No reuse allowed without permission.

(2010): Functional Connectivity Bias of the Orbitofrontal Cortex in Drug-Free Patients with Major Depression. Biol Psychiatry.

https://doi.org/10.1016/j.biopsych.2009.08.022

66. Tak S, Lee S, Park C-A, Cheong E-N, Seok J-W, Sohn J-H, Cheong C (2021): Altered Effective Connectivity within the Fronto-Limbic Circuitry in Response to Negative Emotional Task in Female Patients with Major Depressive Disorder. Brain Connect. https://doi.org/10.1089/brain.2020.0859

67. Chen H, Liu K, Zhang B, Zhang J, Xue X, Lin Y, et al. (2019): More optimal but less regulated dorsal and ventral visual networks in patients with major depressive disorder. J Psychiatr Res.

https://doi.org/10.1016/j.jpsychires.2019.01.005

68. Teng C, Zhou J, Ma H, Tan Y, Wu X, Guan C, et al. (2018): Abnormal resting state activity of left middle occipital gyrus and its functional connectivity in female patients with major depressive disorder 17 Psychology and Cognitive Sciences 1701 Psychology. BMC Psychiatry. https://doi.org/10.1186/s12888-018-1955-9

69. Samara Z, Evers EAT, Peeters F, Uylings HBM, Rajkowska G, Ramaekers JG, Stiers P (2018): Orbital and Medial Prefrontal Cortex Functional Connectivity of Major Depression Vulnerability and Disease. Biol Psychiatry Cogn Neurosci Neuroimaging. https://doi.org/10.1016/j.bpsc.2018.01.004

70. Gray JR, Braver TS, Raichle ME (2002): Integration of emotion and cognition in the lateral prefrontal cortex. Proc Natl Acad Sci U S A.

https://doi.org/10.1073/pnas.062381899

71. Erk S, Kleczar A, Walter H (2007): Valence-specific regulation effects in a working memory task with emotional context. Neuroimage. 
medRxiv preprint doi: https://doi.org/10.1101/2021.04.12.21255310; this version posted April 15, 2021. The copyright holder for this preprint (which was not certified by peer review) is the author/funder, who has granted medRxiv a license to display the preprint in perpetuity.

All rights reserved. No reuse allowed without permission.

https://doi.org/10.1016/j.neuroimage.2007.05.006

72. Dolcos F, Kragel P, Wang L, McCarthy G (2006): Role of the inferior frontal cortex in coping with distracting emotions. Neuroreport. https://doi.org/10.1097/01.wnr.0000236860.24081.be

73. Wessa M, Heissler J, Schönfelder S, Kanske P (2013): Goal-directed behavior under emotional distraction is preserved by enhanced task-specific activation. Soc Cogn Affect Neurosci. https://doi.org/10.1093/scan/nsr098

74. García-Pacios J, Garcés P, Del Río D, Maestú F (2015): Early detection and late cognitive control of emotional distraction by the prefrontal cortex. Sci Rep. https://doi.org/10.1038/srep10046

75. Hooker Cl, Knight RT (2010): The role of lateral orbitofrontal cortex in the inhibitory control of emotion. The Orbitofrontal Cortex. https://doi.org/10.1093/acprof:oso/9780198565741.003.0012

76. Notzon S, Steinberg C, Zwanzger P, Junghöfer M (2018): Modulating Emotion Perception: Opposing Effects of Inhibitory and Excitatory Prefrontal Cortex Stimulation. Biol Psychiatry Cogn Neurosci Neuroimaging. https://doi.org/10.1016/j.bpsc.2017.12.007

77. Minamoto T, Osaka M, Osaka N (2010): Individual differences in working memory capacity and distractor processing: Possible contribution of top-down inhibitory control. Brain Res. https://doi.org/10.1016/j.brainres.2010.03.088

78. Ziaei M, Peira N, Persson J (2014): Brain systems underlying attentional control and emotional distraction during working memory encoding. Neuroimage. https://doi.org/10.1016/j.neuroimage.2013.10.048 
medRxiv preprint doi: https://doi.org/10.1101/2021.04.12.21255310; this version posted April 15, 2021. The copyright holder for this preprint (which was not certified by peer review) is the author/funder, who has granted medRxiv a license to display the preprint in perpetuity. All rights reserved. No reuse allowed without permission.

79. Gasquoine PG (2014): Contributions of the insula to cognition and emotion. Neuropsychology Review. https://doi.org/10.1007/s11065-014-9246-9

80. Pedale T, Macaluso E, Santangelo V (2019): Enhanced insular/prefrontal connectivity when resisting from emotional distraction during visual search. Brain Struct Funct. https://doi.org/10.1007/s00429-019-01873-1

81. Goldin PR, McRae K, Ramel W, Gross JJ (2008): The Neural Bases of Emotion Regulation: Reappraisal and Suppression of Negative Emotion. Biol Psychiatry. https://doi.org/10.1016/j.biopsych.2007.05.031

82. Opel N, Redlich R, Grotegerd D, Dohm K, Zaremba D, Meinert S, et al. (2017): Prefrontal brain responsiveness to negative stimuli distinguishes familial risk for major depression from acute disorder. J Psychiatry Neurosci. https://doi.org/10.1503/jpn.160198

83. Erk S, Mikschl A, Stier S, Ciaramidaro A, Gapp V, Weber B, Walter H (2010): Acute and sustained effects of cognitive emotion regulation in major depression. J Neurosci. https://doi.org/10.1523/JNEUROSCI.1856-10.2010

84. Fales CL, Barch DM, Rundle MM, Mintun MA, Snyder AZ, Cohen JD, et al. (2008): Altered Emotional Interference Processing in Affective and CognitiveControl Brain Circuitry in Major Depression. Biol Psychiatry. https://doi.org/10.1016/j.biopsych.2007.06.012

85. Etkin A, Egner T, Peraza DM, Kandel ER, Hirsch J (2006): Resolving Emotional Conflict: A Role for the Rostral Anterior Cingulate Cortex in Modulating Activity in the Amygdala. Neuron. https://doi.org/10.1016/j.neuron.2006.07.029

86. Etkin A, Egner T, Kalisch R (2011): Emotional processing in anterior cingulate and medial prefrontal cortex. Trends in Cognitive Sciences. 
medRxiv preprint doi: https://doi.org/10.1101/2021.04.12.21255310; this version posted April 15, 2021. The copyright holder for this preprint (which was not certified by peer review) is the author/funder, who has granted medRxiv a license to display the preprint in perpetuity.

https://doi.org/10.1016/j.tics.2010.11.004

87. Kondo H, Osaka N, Osaka M (2004): Cooperation of the anterior cingulate cortex and dorsolateral prefrontal cortex for attention shifting. Neuroimage. https://doi.org/10.1016/j.neuroimage.2004.06.014

88. Comte M, Schön D, Coull JT, Reynaud E, Khalfa S, Belzeaux R, et al. (2016): Dissociating Bottom-Up and Top-Down Mechanisms in the Cortico-Limbic System during Emotion Processing. Cereb Cortex. https://doi.org/10.1093/cercor/bhu185

89. Meyer BM, Rabl U, Huemer J, Bartova L, Kalcher K, Provenzano J, et al. (2019): Prefrontal networks dynamically related to recovery from major depressive disorder: a longitudinal pharmacological fMRI study. Transl Psychiatry. https://doi.org/10.1038/s41398-019-0395-8

90. Kessler RC, Berglund P, Demler O, Jin R, Merikangas KR, Walters EE (2005): Lifetime prevalence and age-of-onset distributions of DSM-IV disorders in the national comorbidity survey replication. Archives of General Psychiatry. https://doi.org/10.1001/archpsyc.62.6.593

91. Zeidman P, Jafarian A, Seghier ML, Litvak V, Cagnan H, Price CJ, Friston KJ (2019): A guide to group effective connectivity analysis, part 2: Second level analysis with PEB. Neuroimage.

https://doi.org/10.1016/j.neuroimage.2019.06.032

92. Koush Y, Rosa MJ, Robineau F, Heinen K, W. Rieger S, Weiskopf N, et al. (2013): Connectivity-based neurofeedback: Dynamic causal modeling for realtime fMRI. Neuroimage. https://doi.org/10.1016/j.neuroimage.2013.05.010

93. Paret C, Ruf M, Gerchen MF, Kluetsch R, Demirakca T, Jungkunz M, et al. 
medRxiv preprint doi: https://doi.org/10.1101/2021.04.12.21255310; this version posted April 15, 2021. The copyright holder for this preprint (which was not certified by peer review) is the author/funder, who has granted medRxiv a license to display the preprint in perpetuity.

All rights reserved. No reuse allowed without permission.

(2016): FMRI neurofeedback of amygdala response to aversive stimuli enhances prefrontal-limbic brain connectivity. Neuroimage.

https://doi.org/10.1016/j.neuroimage.2015.10.027

94. Young KD, Siegle GJ, Misaki M, Zotev V, Phillips R, Drevets WC, Bodurka J (2018): Altered task-based and resting-state amygdala functional connectivity following real-time fMRI amygdala neurofeedback training in major depressive disorder. Neurolmage Clin. https://doi.org/10.1016/j.nicl.2017.12.004

95. Linhartová P, Látalová A, Kóša B, Kašpárek T, Schmahl C, Paret C (2019): fMRI neurofeedback in emotion regulation: A literature review. Neuroimage. https://doi.org/10.1016/j.neuroimage.2019.03.011 
medRxiv preprint doi: https://doi.org/10.1101/2021.04.12.21255310; this version posted April 15, 2021. The copyright holder for this preprint (which was not certified by peer review) is the author/funder, who has granted medRxiv a license to display the preprint in perpetuity.

All rights reserved. No reuse allowed without permission.

\section{Tables}

Table 1. Locations of Regions of Interest.

\begin{tabular}{|c|c|c|}
\hline Regions of Interest & MNI Coordinates & $\mathbf{T}$ \\
\hline Fusiform Gyrus L & $-36-73-13$ & 29.69 \\
\hline Fusiform Gyrus R & $39-55-16$ & 28.29 \\
\hline Amygdala $L$ & $\begin{array}{lll}-24 & -4 & -19\end{array}$ & 13.88 \\
\hline Amygdala $\mathrm{R}$ & $\begin{array}{lll}27 & -4 & -19\end{array}$ & 14.55 \\
\hline Anterior Cingulate Cortex & $926 \quad 20$ & 7.00 \\
\hline Dorsolateral Prefrontal Cortex L & $\begin{array}{lll}-51 & 29 & 23\end{array}$ & 13.39 \\
\hline Dorsolateral Prefrontal Cortex R & $5432 \quad 20$ & 17.59 \\
\hline Orbitofrontal Cortex L & $-36 \quad 32-16$ & 12.19 \\
\hline Orbitofrontal Cortex $\mathrm{R}$ & $33 \quad 32-16$ & 14.73 \\
\hline Insula L & $-3623-1$ & 8.10 \\
\hline Insula R & $3629-1$ & 9.00 \\
\hline
\end{tabular}

Regions of Interest were located at group-level peak MNI coordinates of the faces $>$ shapes contrast at a significance threshold of $p<0.05$ (FWE-corrected). 
medRxiv preprint doi: https://doi.org/10.1101/2021.04.12.21255310; this version posted April 15, 2021. The copyright holder for this preprint (which was not certified by peer review) is the author/funder, who has granted medRxiv a license to display the preprint in perpetuity.

All rights reserved. No reuse allowed without permission.

Table 2. Sample Characteristics.

\begin{tabular}{|c|c|c|c|c|c|c|}
\hline & $\begin{array}{l}\text { Controls } \\
(\mathrm{N}=103)\end{array}$ & $\begin{array}{l}\text { Relatives } \\
(\mathrm{N}=49)\end{array}$ & $\begin{array}{l}\text { Patients } \\
(\mathrm{N}=48)\end{array}$ & df & $F X^{2}$ & p \\
\hline \multicolumn{7}{|l|}{ Demographics } \\
\hline Sex, M/F, N & $42 / 61$ & $16 / 33$ & $14 / 34$ & 2 & 2.23 & 0.33 \\
\hline Age (y), M (SD) & $31.25(9.33)$ & $28.49(8.11)$ & $31.88(8.97)$ & 197 & 2.10 & 0.12 \\
\hline Education (y), M (SD) & $14.14(2.89)$ & $14.49(2.80)$ & $14.78(2.19)$ & 2 & 0.92 & 0.40 \\
\hline Study Site, N & & & & 4 & 26.76 & $<0.001^{\mathrm{a}}$ \\
\hline Bonn & 13 & 16 & 0 & & & \\
\hline Mannheim & 30 & 15 & 25 & & & \\
\hline Berlin & 60 & 18 & 23 & & & \\
\hline Mean Head Motion, Mdn (IQR) & $0.09(0.05)$ & $0.08(0.04)$ & $0.12(0.10)$ & 197 & 12.67 & $0.002^{\mathrm{a}}$ \\
\hline \multicolumn{7}{|l|}{$\begin{array}{l}\text { Type of Familial Relationship, } \\
\mathrm{N}\end{array}$} \\
\hline Offspring/Sibling/Parent & & $35 / 12 / 1$ & & & & \\
\hline \multicolumn{7}{|l|}{ Task Performance } \\
\hline \multicolumn{7}{|l|}{ Reaction Time, sec, M (SD) } \\
\hline Shapes & $1.11(0.21)$ & $1.12(0.29)$ & $1.12(0.19)$ & 197 & 0.02 & 0.98 \\
\hline Faces & $1.21(0.24)$ & $1.25(0.30)$ & $1.19(0.19)$ & 197 & 0.74 & 0.48 \\
\hline \multicolumn{7}{|l|}{ Accuracy, n (\%) } \\
\hline Shapes & 23.18(96.58) & 23.32(97.21) & 23.27(96.96) & 196 & 0.22 & 0.80 \\
\hline Faces & $23.64(98.5)$ & 23.67(98.62) & 23.75(98.96) & 196 & 0.19 & 0.83 \\
\hline \multicolumn{7}{|l|}{ Psychological Measurements } \\
\hline SCL-90 Depression, Mdn (IQR) & $0.08(0.29)$ & $0.08(0.27)$ & $1.54(1.27)$ & 197 & 88.26 & $<0.001^{\mathrm{a}}$ \\
\hline BDI, Mdn (IQR) & $1(3.5)$ & $3(4.5)$ & $21(16.5)$ & 197 & 99.78 & $<0.001^{\mathrm{a}}$ \\
\hline STAI-S, M (SD) & $31.56(6.51)$ & $31.85(5.32)$ & $49.72(10.89)$ & 162 & 89.88 & $<0.001^{\mathrm{a}}$ \\
\hline STAI-T, M (SD) & $33.46(8.43)$ & $35.76(8.10)$ & $56.53(10.65)$ & 191 & 112.32 & $<0.001^{\mathrm{a}}$ \\
\hline NEO-FFI Neuroticism, M (SD) & $14.32(6.62)$ & $17.5(6.99)$ & $32.53(8.04)$ & 193 & 110.80 & $<0.001^{\mathrm{a}}$ \\
\hline Negative Affect, Mdn (IQR) & $-0.56(0.60)$ & $-0.35(0.73)$ & $1.59(0.98)$ & 191 & 52.95 & $<0.001^{\mathrm{a}}$ \\
\hline
\end{tabular}

a $p<0.05$

Abbreviations: BDI, Beck's Depression Inventory; HDRS, Hamilton Depression Rating Scale; NEO, NEO-Five Factory Inventory; SCL90-R Depression, Symptom Checklist 90 Revised Depression Scale;STAI-S, State Trait Anxiety Inventory - State Anxiety; STAI-T, State Trait Anxiety Inventory - Trait Anxiety 
medRxiv preprint doi: https://doi.org/10.1101/2021.04.12.21255310; this version posted April 15, 2021. The copyright holder for this preprint (which was not certified by peer review) is the author/funder, who has granted medRxiv a license to display the preprint in perpetuity.

All rights reserved. No reuse allowed without permission.

Table 3. Between-group differences of effective connectivity during the face-matching task.

\begin{tabular}{|c|c|c|}
\hline $\begin{array}{l}\text { Connection } \\
\text { Parameter }\end{array}$ & $\begin{array}{c}\text { Effect size } \\
\text { (Posterior } \\
\text { Expectation) }\end{array}$ & $\begin{array}{c}95 \% \text { Bayesian } \\
\text { Confidence } \\
\text { Interval }\end{array}$ \\
\hline
\end{tabular}

\section{Controls > Patients}

\section{Controls < Patients}

$\begin{array}{lll}\text { AMG } R \rightarrow \text { FG R } & 0.04 & {[0.01,0.06]} \\ \text { AMG } R \rightarrow \text { FG L } & 0.03 & {[-0.001,0.05]} \\ \text { OFC R } \rightarrow \text { INS L } & 0.03 & {[0.01,0.05]} \\ \text { AMG L } \rightarrow \text { FG R } & 0.07 & {[0.04,0.10]} \\ \text { OFC L } \rightarrow \text { FG R } & 0.07 & {[0.05,0.10]} \\ \text { OFC L } \rightarrow \text { FG L } & 0.08 & {[0.05,0.12]} \\ \text { dIPFC L } \rightarrow \text { FG R } & 0.09 & {[0.06,0.12]} \\ \text { dIPFC L } \rightarrow \text { OFC R } & 0.04 & {[0.01,0.06]} \\ \text { dIPFC L } \rightarrow \text { dIPFC R } & 0.03 & {[0.00,0.06]} \\ \text { dIPFC L } \rightarrow \text { FG L } & 0.09 & {[0.06,0.12]} \\ \text { dIPFC L } \rightarrow \text { AMG L } & 0.03 & {[-0.001,0.06]} \\ \text { dIPFC L } \rightarrow \text { INS L } & 0.02 & {[-0.01,0.05]}\end{array}$

$\begin{array}{lll}\text { dIPFC R } \rightarrow \text { FG R } & -0.02 & {[-0.05,0.001]} \\ \text { AMG L } \rightarrow \text { INS L } & -0.02 & {[-0.05,-0.000]}\end{array}$

Relatives > Patients

$\begin{array}{lll}\text { ACC } \rightarrow \text { dIPFC L } & 0.03 & {[0.01,0.05]} \\ \text { ACC } \rightarrow \text { INS L } & 0.02 & {[0.000,0.03]} \\ \text { AMG L } \rightarrow \text { FG R } & 0.06 & {[0.03,0.09]} \\ & & \\ \text { OFC L } \rightarrow \text { FG L } & 0.05 & {[0.02,0.08]} \\ \text { dIPFC L } \rightarrow \text { FG R } & 0.08 & {[0.05,0.12]} \\ \text { INS L } \rightarrow \text { FG R } & 0.07 & {[0.04,0.10]} \\ \text { INS L } \rightarrow \text { OFC L } & 0.05 & {[0.02,0.08]}\end{array}$

Controls > Relatives

$\begin{array}{lll}\text { OFC R } \rightarrow \text { FG L } & 0.04 & {[0.02,0.06]} \\ \text { OFC R } \rightarrow \text { INS L } & 0.02 & {[0.00,0.04]} \\ \text { OFC L } \rightarrow \text { FG R } & 0.04 & {[0.01,0.06]}\end{array}$

\section{Controls $<$ Relatives}

$\begin{array}{lll}\text { ACC } \rightarrow \text { AMG L } & -0.01 & {[-0.02,0.001]} \\ \text { ACC } \rightarrow \text { dIPFC L } & -0.02 & {[-0.04,-0.003]} \\ \text { FG L } \rightarrow \text { FG R } & -0.03 & {[-0.05,-0.01]}\end{array}$

Abbreviations. ACC, anterior cingulate cortex; AMG, amygdala; dIPFC, dorsolateral prefrontal cortex; FG, fusiform gyrus; INS, insula; L, left; OFC, orbitofrontal cortex; R, right. 


\section{Figures}

A Task-Positive (Faces > Shapes)

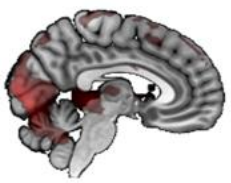

$x=5$

B

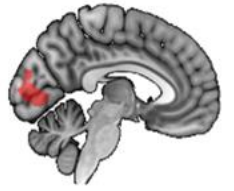

$x=5$

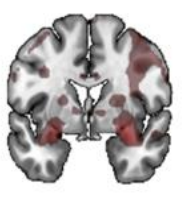

$y=1$
Controls > Patients

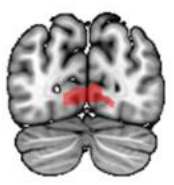

$y=-77$

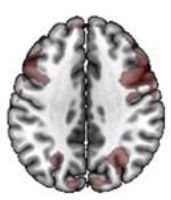

$z=37$

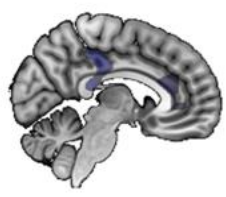

$x=6$

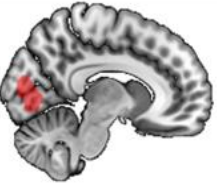

$x=9$

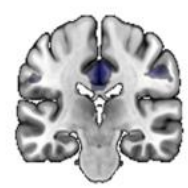

$y=-24$

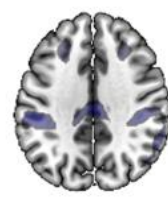

$z=36$

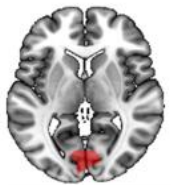

$z=4$
Relatives > Patients

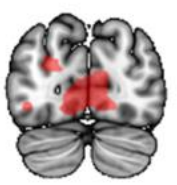

$y=-80$

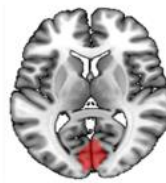

$z=9$

Figure 1. Task-related brain activity across and between groups. The upper panel (A) shows brain regions exhibiting increased (left panel, red color) and decreased (right panel, blue color) activation during the face-matching condition compared to the shape-matching condition ( $p<0.05$; whole-brain FWE corrected). The lower panel (B) shows group differences in the task-related activation in healthy controls (left panel) and first-degree relatives (right panel) compared to patients with MDD. Here, red color indicates increased regional responses during the face-matching condition relative to the shape-matching condition in the respective group comparison. 

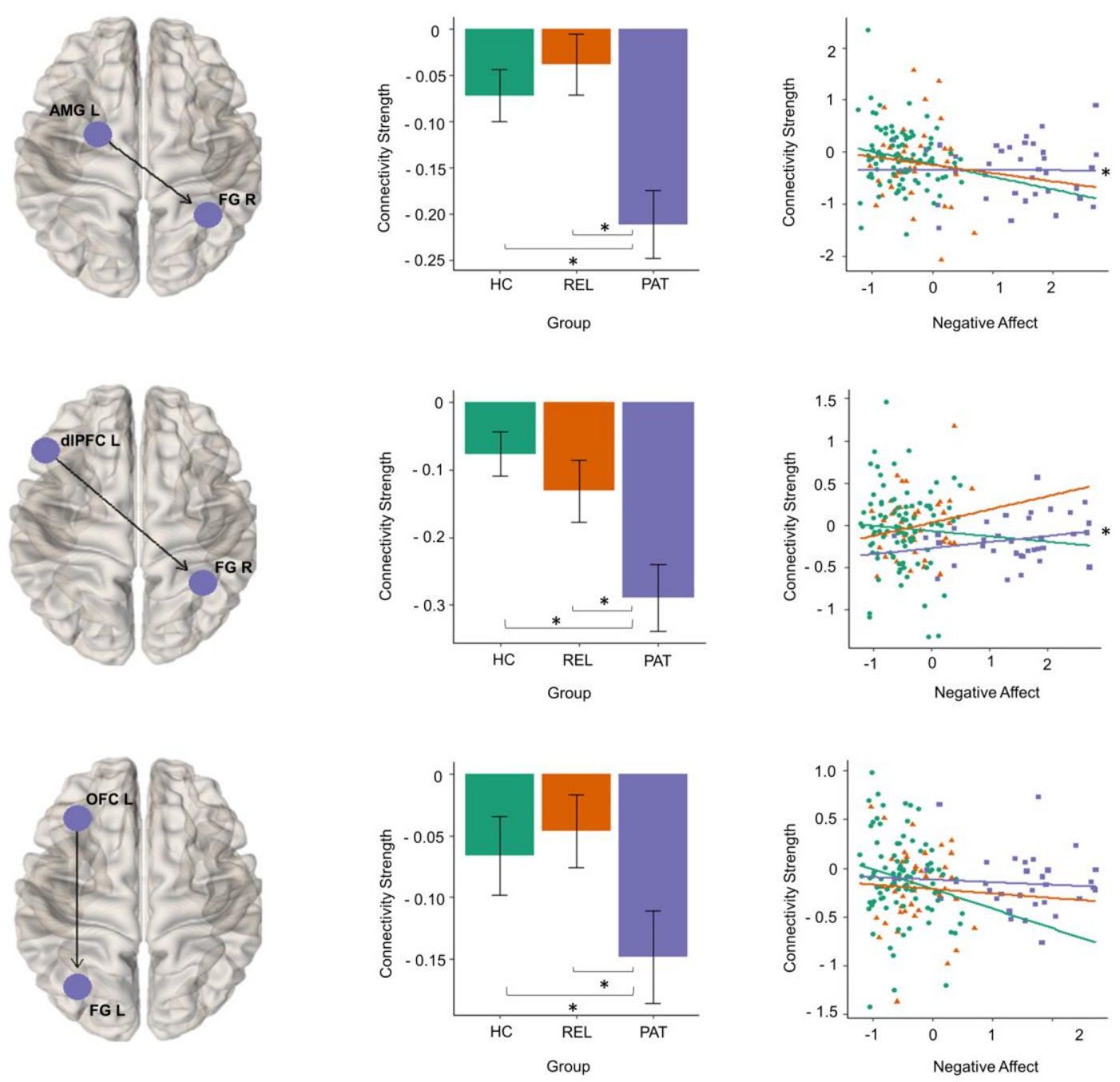

Figure 2. Disease-related alterations in effective connectivity. The middle panel shows the group means of the effective connection parameters which were associated with depressive pathology. Error bars indicate 95\% Bayesian confidence interval. Group differences with strong evidence (i.e., posterior probability (free energy with versus without parameter) are larger than .95) are marked with an asterisk. Negative affect scores and estimated posterior means of connection parameters are plotted in the right panel for visualization. The associations with strong evidence are marked with an asterisk. Abbreviations. HC, healthy controls; PAT, patients with major depression; REL, first-degree relatives of patients with depression. 

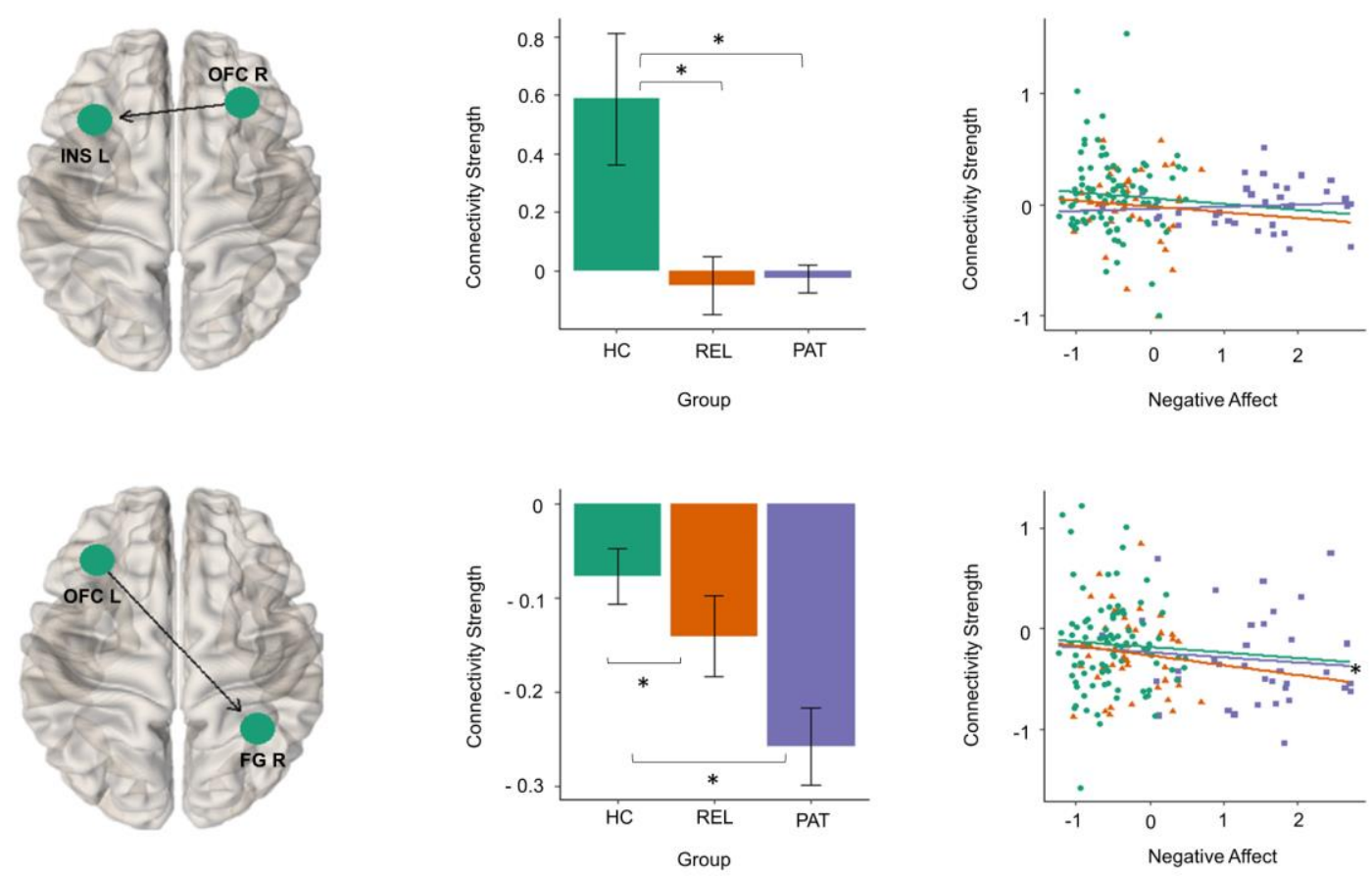

Figure 3. Risk-related alterations in effective connectivity. The middle panel shows the group means of the effective connection parameters which were associated with risk for depression. Error bars indicate a 95\% Bayesian confidence interval. Group differences with strong evidence are marked with an asterisk. Negative affect scores and estimated posterior means of connection parameters are plotted in the right panel for visualization. Associations with strong evidence are marked with an asterisk. Abbreviations. HC, healthy controls; PAT, patients with major depression; REL, firstdegree relatives of patients with depression. 

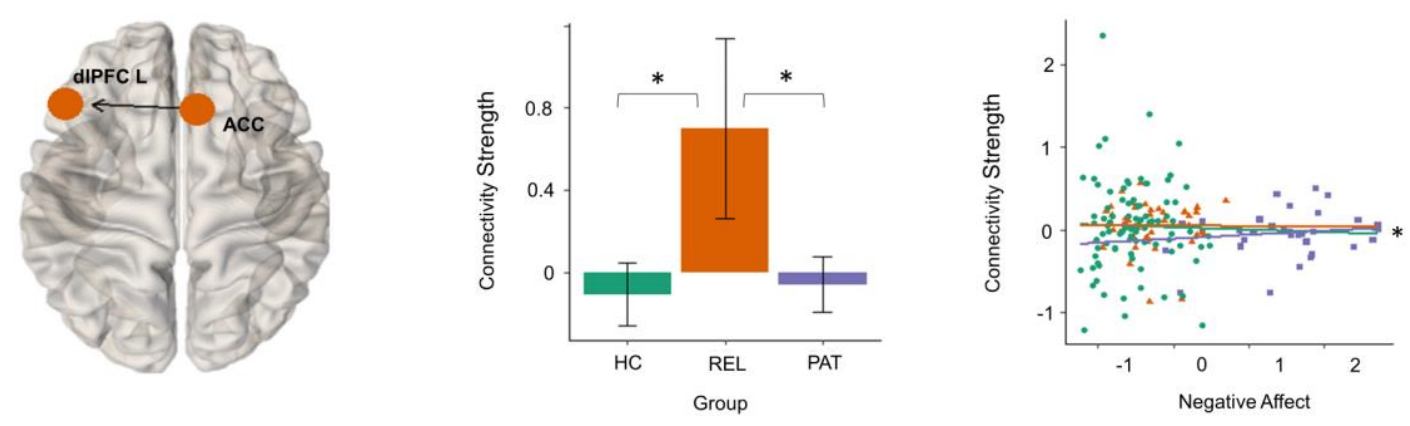

Figure 4. Resilience-related alterations in effective connectivity. The middle panel shows the group means of the effective connection parameter which was associated with resilience. Error bars indicate 95\% Bayesian confidence interval. Group differences with strong evidence are marked with asterisk. Negative affect scores and estimated posterior means of connection parameters are plotted in the right panel for visualization. Associations with strong evidence are marked with an asterisk. Abbreviations. HC, healthy controls; PAT, patients with major depression; REL, firstdegree relatives of patients with depression. 